\title{
Pengembangan LKPD Berbasis Keterampilan Proses pada Materi Klasifikasi Tumbuhan untuk Melatihkan Keterampilan Proses Sains Siswa Kelas X SMAS Katolik St. Gabriel Maumere
}

\author{
Yohanes B. Tematan ${ }^{1), *}$, Oktavius Y.T Mago ${ }^{1)}$ \\ ${ }^{1)}$ Program Studi Pendidikan Biologi, Fakultas Keguruan dan Ilmu Pendidikan, Universitas Nusa Nipa \\ *yohanestematan@gmail.com
}

\begin{abstract}
Abstrak: Penelitian ini adalah penelitian pengembangan dengan mengacu pada model pengembangan $4 \mathrm{D}$ yang bertujuan untuk mengembangkan Lembar Kerja Peserta Didik (LKPD) berbasis keterampilan proses pada materi klasifikasi tumbuhan yang valid, praktis dan efektif. Lembar Kerja Peserta Didik divalidasi oleh pakar kemudian dilakukan revisi dan selanjutnya LKPD yang telah direvisi siap digunakan pada kelas sampel. Hasil penelitian menunjukkan bahwa validitas LKPD berdasarkan aspek kelayakan isi 95,38\%, aspek kebahasaan $100 \%$, aspek penyajian 98,75\%, aspek kegrafisan 97,5\% dan aspek keterampilan proses sains $100 \%$ dengan kategori sangat layak. Kepraktiasan LKPD berdasarkan aspek aktivitas siswa 96\% dengan kategori sangat aktif dan respon siswa dengan persentase sebesar 97,74\% dengan kategori sangat baik. Keefektifan LKPD berdasarkan peningkatan hasil tes keterampilan proses sains dengan N-Gain sebesar 0.64 (sedang). Lembar Kerja Peserta Didik (LKPD) pada materi klasifikasi tumbuhan yang dikembangkan dapat memberi efek dalam melatihkan keterampilan proses mengamati, mengklasifikasikan dan mengomunikasikan.
\end{abstract}

Kata kunci: Keterampilan Proses, Klasifikasi Tumbuhan, Lembar Kerja Peserta Didik, Research and Development.

\section{PENDAHULUAN}

Kurikulum 2013 menghendaki agar pembelajaran dilaksanakan dengan pendekatan ilmiah, dimana peserta didik diharapkan memiliki kemampuan untuk menggali informasi melalui kegiatan mengamati, mengklasifikasikan dan mengkomunikasikan. Pembelajaran biologi merupakan bagian dari ilmu sains yang lebih menekankan pada kegiatan belajar mengajar, mengembangkan konsep dan keterampilan proses siswa dengan berbagai strategi belajar mengajar yang sesuai dengan materi yang diajarkan.

Keterampilan proses memberikan kesempatan kepada siswa untuk bertindak secara nyata sebagai seorang ilmuwan. Keterampilan proses sains mengajak untuk melakukan proses pencarian pengetahuan berkenaan dengan materi pelajaran melalui berbagai aktivitas proses sains sebagaimana dilakukan oleh ilmuwan dalam penelitian ilmiah. Keterampilan proses sains adalah keterampilan fisik dan mental berkenaan dengan kemampuan-kemampuan yang mendasar yang dimiliki, dikuasai, dan diaplikasikan dalam suatu kegiatan ilmiah, sehingga siswa berhasil menemukan sesuatu yang baru yang berhubungan dengan sains.

Lembar Kerja Peserta Didik (LKPD) yang digunakan oleh guru, khususnya di SMAS Katolik St. Gabriel Maumere masih berupa soal latihan yang diambil dari buku sehingga belum dapat membangun keterampilan proses sains siswa. Untuk mengatasi hal tersebut, pembelajaran seharusnya menggunakan LKPD yang berbasis keterampilan proses agar siswa dapat belajar dan maju sesuai dengan kecepatan masing-masing, siswa akan memperoleh pengalaman belajar yang sama dengan siswa lain, pengalaman ini membuat pembelajaran menjadi lebih bermakna dan mudah diingat oleh siswa. Materi pelajaran juga dapat dirancang sedemikian rupa sehingga mampu memenuhi kebutuhan siswa (Arsyad, 2013).

Penggunaan LKPD yang dikembangkan berbasis keterapilan proses sains pada materi klasifikasi tumbuhan diharapkan dapat melatihkan keterampilan siswa untuk mengamati, mengklasifikasi dan mengkomunikasikan sehingga siswa dapat menemukan sendiri fakta dan konsepnya serta dapat menumbuhkembangkan sikap dan nilai yang dituntut. Lembar Kerja Peserta Didik berbasis keterampilan proses 
sains dapat memberikan pengalaman langsung kepada siswa karena siswa dapat mencari informasi dan mendapatkan konsep materi dengan sendirinya melalui prosedur yang ada di dalam Lembar Kerja Peserta Didik. Pengunaan LKPD disertai spesimen awetan dapat melatih keterampilan proses sains dan siswa dapat menemukan sendiri fakta dan konsep yang dipelajarinya melalui serangkaian kegiatan penyelidikan ilmiah melalui benda nyata sebagai objek yang diamatinya (Setiawan dkk, 2014).

\section{METODE PENELITIAN}

Jenis penelitian ini adalah penelitian pengembangan (Research dan Development) yang mengacu pada model 4D (Four D Model) yang terdiri atas 4 tahap utama yaitu: tahap pendefenisian (Define), perancangan (Design), pengembangan (Development), dan penyebaran (Disseminate), namun peneliti hanya sampai pada tahap ketiga, yaitu tahap pengembangan. Penelitian ini mengembangkan Lembar Kerja Peserta Didik (LKPD) berbasis keterampilan proses yang selanjutnya dilakukan beberapa pegujian, yaitu validasi dari pakar untuk mengetahui tingkat kevalidan, uji coba skala kecil dan skala besar untuk mengetahui kepraktisan dan efektivitas LKPD serta instrument tes digunakan pada kelas sampel memenuhi kriteria valid dan reliabel, memiliki tingkat kesukaran beragam dan instrument tes tergolong dalam kategori baik. Sampel penelitian ini adalah siswa kelas X MIA SMAS Katolik St. Gabriel Maumere. Hasil validasi LKPD dengan kriteria 85-100\% kategori sangat valid, 7084,9\% kategori valid, 55-69,9\% kategori cukup valid, 40-54,9\% kategori kurang valid dan 25-39,9 dengan kategori tidak valid (Isnani \& Nuraida, D, 2020) Data tes hasil belajar pada uji coba skala besar dianalisis dengan mengunakan N-Gain untuk mengetahui efektifitas LKPD dengan kriteria pembelajaran dengan gain tinggi jika $\mathrm{N}$-Gain $\geq 0.7$, pembelajaran dengan gain sedang jika $0,7>\mathrm{N}$-Gain $\geq 0,3$ dan pembelajaran dengan gain rendah jika N-Gain <0,3 (H Dewi, R Agustini \& E Susantini,2017).

\section{HASIL DAN PEMBAHASAN}

\section{Hasil Validasi LKPD}

Lembar kerja Peserta Didik (LKPD) merupakan pedoman proses dalam pembelajaran yang dapat membantu siswa dalam belajar untuk menemukan dan mengembangkan konsep- konsep yang sedang dipelajari siswa. Hasil penilaian LKPD disajikan pada Tabel 1.

Tabel 1. Hasil Validasi LKPD

\begin{tabular}{clccccc}
\hline \multirow{2}{*}{ No } & \multirow{2}{*}{ Aspek yang dinilai } & \multicolumn{2}{c}{ Skor } & \multirow{2}{*}{ Rata- rata } & \multirow{2}{*}{ Persentase (\%) } & \multirow{2}{*}{ Kategori } \\
\cline { 2 - 3 } & V1 & V2 & & & \\
\hline 1 & Aspek kelayakan isi & 3,88 & 3,75 & 3,8 & 95,38 & Sangat Valid \\
2 & Aspek kebahasaan & 4 & 4 & 4 & 100 & Sangat Valid \\
3 & Aspek penyajian & 4 & 3,9 & 3,95 & 98.75 & Sangat Valid \\
4 & Aspek kegrafisan & 3,8 & 4 & 3,9 & 97.5 & Valid \\
5 & Aspek KPS & 4 & & 4 & 100 & Sangat Valid \\
\hline \multicolumn{2}{c}{ Rata- rata Total } & & 3,93 & 98,32 & Sangat Valid \\
\hline
\end{tabular}

Hasil validasi LKPD yang dikembangkan termasuk dalam kategori sangat valid dan dapat digunakan untuk melatihkan keterampilan proses sains siswa untuk mengamati jenis tumbuhan dengan menggunakan pancaindera seperti: melihat, menyentuh, meraba untuk mendapatkan informasi dari jenis- jenis tumbuhan, menggolongkan jenis tumbuhan sesuai dengan divisinya berdasarkan persamaan dan perbedaan ciri, dan mengomunikasikan hasil pengamatan terhadap kelompok peserta didik lain. Pembelajaran menggunakan perangkat pembelajaran yang relevan dapat meningkatkan motivasi siswa dan mempermudah pemahaman konsep pembelajaran (Dewi R, Karno.R \& Purnama A.A, 2014). Hal ini juga didukung dengan respon siswa bahwa LKPD klasifikasi tumbuhan yang dikembangkan sesuai dengan syarat LKPD yang baik, materi yang tercantum pada LKPD sesuai dengan kompentensi yang diajarkan.

\section{Analisis Hasil Respon Guru dan Respon Siswa}

Uji coba produk yang dilakukan pada dua orang guru biologi yang mengajar di SMAS Katolik St. Gabriel Maumere dan 31 orang siswa kelas X MIA I. Dari hasil tanggapan guru dikategorikan sangat baik dan memiliki manfaat, menambah wawasan bagi siswa dan bisa diterapkan di sekolah. Hasil analisis data persepsi siswa terhadap LKPD yang dikembangkan sebesar 97,98 \% (kategori sangat baik) sehingga dapat dijadikan sebagai 
sumber belajar bagi siswa dan sangat memberi efek pada hasil belajar. Hasil respon menunjukkan bahwa petunjuk belajar dalam LKPD berbasis keterampilan proses sangat baik, sehingga siswa mudah untuk memahami dan mengikuti proses pembelajaran sesuai dengan petunjuk atau arahan di dalam LKPD pada materi klasifikasi tumbuhan.

Hasil penelitian ini senada dengan hasil penelitian Tarmizi (2010) siswa menyatakan bahwa penerapan pendekatan keterampilan proses membuat siswa sangat mudah memahami materi, cara guru dalam menyajikan materi pembelajaran dengan penerapan model keterampilan proses menarik. Semangat siswa dalam mengikuti pembelajaran berkaitan keterampilan proses dengan adanya LKPD mampu menumbuhkan semangat dalam belajar. Sesuai dengan pendapat Isnahningsih (2013), LKPD memiliki fungsi mampu meningkatkan keterampilan proses sains siswa agar lebih aktif belajar dan menumbuhkan keterampilan siswa dalam belajar. Siswa memberikan respon yang baik terhadap kegiatan pembelajaran, hal ini karena siswa sangat tertarik terhadap pembelajaran dengan menggunakan LKPD berbasis keterampilan proses sains. Hal ini sejalan dengan penelitian yang dilakukan Jaya dkk (2014) bahwa respon positif yang diberikan oleh siswa terhadap pembelajaran yang telah dilakukan karena ketertarikan siswa terhadap metode yang digunakan dalam pembelajaran yang memberikan pengalaman langsung pada siswa dimulai dari mengamati, mangajukan pertanyaan, mengumpulkan informasi, mengasosiasi atau mengolah informasi, dan mengkomunikasikan hasil yang diperoleh.

Hasil ini dibuktikan dari antusiasme siswa yang ditunjukkan pada saat uji coba lapangan dengan menerapkan LKPD klasifikasi tumbuhan untuk mengamati jenis tumbuhan paku, tumbuhan lumut, mengamati tumbuhan yang termasuk gymnospermae dan angiospermae, mengamati jenis tumbuhan memiliki manfaat bagi kehidupan di sekitar lingkungan sekolah.

\section{Hasil Analisis Data Aktivitas Siswa}

Data pengamatan aktivitas siswa dianalisis dengan teknik deskriptif kualitatif untuk mendeskripsikan aktivitas siswa dalam pembelajaran.

Tabel 2. Hasil Analisis Aktivitas Siswa

\begin{tabular}{cccc}
\hline No & Pertemuan & Ketercapaian Indikator (\%) & Kategori \\
\hline 1 & I & 95.88 & Sangat Baik \\
2 & II & 95.31 & Sangat Baik \\
3 & III & 96.81 & Sangat Baik \\
\hline Rata-Rata Ketercapaian Indikator & 96 & Sangat Baik \\
\hline
\end{tabular}

Hasil pengamatan aktivitas siswa selama kegiatan pembelajaran berlangsung, diperoleh persentase masingmasing aspek kertercapaian indikator mengalami peningkatan pada pertemuan ke-3 dalam hal ini tampak bahwa aktivitas siswa dalam belajar sudah baik dan presentase rata- rata aktivitas 96,81\% termasuk dalam kategori sangat baik atau sangat aktif.

Aktivitas siswa selama proses pembelajaran berlangsung terus meningkat pada setiap pertemuan untuk mengerjakan LKPD berbasis keterampilan proses sains. Hal ini sejalan dengan pendapat Sudarmini dkk (2015) bahwa peran guru sangat penting untuk dapat mendorong dan menumbuhkan aktivitas siswa selama proses pembelajaran dengan menggunakan sumber belajar yang mendukung yakni LKPD. Untuk itu, guru dapat menciptakan kegiatan pembelajaran dengan mengadakan pengamatan jenis tumbuhan di sekitar lingkungan, dengan berbantuan LKPD yang telah dikembangkan, sehingga siswa dapat lebih memahami materi yang diajarkan. Penggunaan media di dalam pembelajaran berkaitan dengan fungsi kognitif yaitu menambah wawasan siswa terkait informasi atau pesan yang disampaikan sehingga berpengaruh pada hasil belajarnya. Strategi pembelajaran yang relevan dengan media yang digunakan dalam pembelajaran dapat memberikan pengalaman belajar yang dapat mengembangkan potensi siswa (Isnani \& Nuraida D, 2020)

\section{Analisis Hasil Pretest Dan Postest}

Hasil analisis data pretest dan postest menunjukka terjadi peningkatan hasil belajar setelah menggunakan LKPD yang dikembangkan. Gambar 1 menunjukkan perbedaaan nilai prestest dan postest yakni rata- rata tes kemampuan pada tes awal 49,76 dengan kategori cukup dan rata- rata pada tes akhir 77.34 dengan kategori baik. 
Hasil ini menunjukkan bahwa LKPD berbasis keterampilan proses dapat digunakan untuk meningkatkan kemampuan siswa.

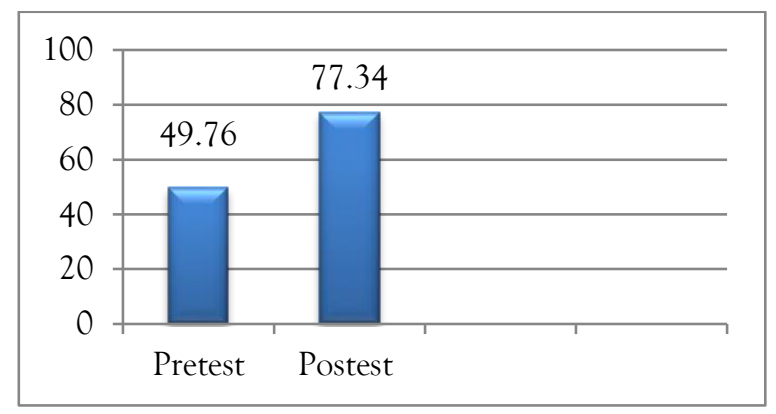

Gambar 1. Rata- rata Nilai Pretest dan Postest

Pre-test dan post-test yang diberikan dalam proses belajar dan mengajar mempengaruhi kemajuan belajar siswa bermanfaat sebagai jembatan yang menghubungkan antara apa yang sedang dipelajari dan apa yang akan dipelajari, sehingga siswa mampu memahami materi yang diajarkan. Siswa akan belajar dengan baik jika apa yang disebut dengan Advance Organizations didefenisiskan dan dipresentasikan dengan baik. Hasil belajar adalah pengalaman atau tingkah laku yang dimiliki seseorang sebagai akibat dari suatu proses belajar, yang tercermin dalam bentuk kecakapan, keterampilan dan sikap (Aflaha,D.S.I, Suparmi \& Sarwanto, 2015)

\section{Analisis Gain Skor}

Analisis G-skor menunjukkan bahwa pemahaman konsep siswa lebih baik (meningkat) setelah pembelajaran dengan menggunakan LKPD berbasis keterampilan proses dengan rata- rata G-skor 0.64 berada pada kategori sedang. Pembelajaran dengan menggunakan lembar kerja peserta didik berbasis keterampilan proses pada kelas sampel menitikberatkan pada aktivitas siswa untuk mencari tahu sendiri permasalahan yang dihadapi yang diimplementasikan dalam kegiatan pengamatan. Siswa melakukan kegiatan pengamatan pada materi klasifikasi tumbuhan dengan menerapkan LKPD klasifikasi tumbuhan untuk mengamati berbagai jenis tumbuhan di sekitar lingkungan sekolah. Penggunaan LKPD pada materi klasifikasi tumbuhan dengan menggunakan pembelajaran berbasis keterampilan proses dapat digunakan guru sebagai salah satu alternatif media untuk meningkatkan pemahaman konsep siswa. LKPD sangat penting digunakan oleh siswa dalam bentuk individual maupun dalam bentuk kelompok sehingga siswa dapat menyelesaikan tugas yang diberikan guru. Kurmanto dan Sujari (2014) menyatakan bahwa penggunaan LKPD dapat digunakan sebagai penunjang untuk meningkatkan aktivitas siswa dalam proses belajar yang dapat mengoptimalkan prestasi belajar. Peran LKPD dalam proses pembelajaran adalah sebagai alat untuk memberikan pengetahuan dan keterampilan proses siswa.

Peningkatan kemampuan kerja ilmiah disebabkan beberapa faktor yaitu proses pembelajaran harus didesain menjadi proses merekonstruksi, bukan menerima informasi atau pengetahuan dari guru (Hidayati, 2016). Adanya peningkatan juga dikarenakan penggunaan LKPD berbasis keterampilan proses sains dalam pembelajaran mencantumkan kegiatan keterampilan proses sains dan melibatkan siswa secara aktif dan dapat mengkonstruksi pengetahuannya. Prastowo (2011) menyatakan LKPD mempermudah siswa untuk memahami materi. Astuti (2013) menyatakan bahwa LKPD merupakan panduan bagi siswa untuk memahami keterampilan proses sains dengan memfokusakan pada tercapainya kompetensi yang diharapkan dan berpusat pada siswa. Jhon Dewey dalam Trianto (2011) pendidik harus melakukan pengajaran dan pembelajaran yang bertujuan untuk menyusun pengelaman secara berkesinambungan dan siswa harus ikut serta dalam aktivitas pembelajaran.

\section{SIMPULAN}

Lembar Kerja Peserta Didik pada materi klasifikasi tumbuhan yang dikembangkan dinyatakan sangat valid dan praktis digunakan dalam pembelajaran pada kelas sampel serta mampu melatihkan keterampilan proses sains siswa. Hasil analisis data pre-test dan post-test menunjukkan bahwa pembelajaran dengan menggunakan LKPD yang dikembangkan dapat memberikan efek terhadap keterampilan proses sains siswa. Efek pembelajaran ini didukung dengan data respon siswa yang sangat baik terhadap LKPD yang dikembangkan berbasis keterampilan proses sains sehingga dapat digunakan sebagai salah satu penunjang dalam pembelajaran di sekolah lain. 


\section{Daftar Pustaka}

Aflaha, D. S. I., Suparmi2, \& Sarwanto. (2015). Pengembangan Modul Fisika Berbasis Problem Solving Materi Elastisitas untuk siswa kelas x SMA/MA. Http://Jurnal.Fkip.Uns.Ac.Id/Index.Php/Sains, 4, 63-72.

Arsyad, A. (2013). Media Pembelajaran. Jakarta: PT Raja Grafindo Persada.

Astuti (2013). Lembar Kerja Siswa (LKPD) Berbasis Pendekatan Inkuiri Terbimbing dalam Pembelajaran Kooperatif pada Materi Kalor. Jurnal Pendidikan IPA Indonesia.

Dewi, R., Karno, R., \& Purnama, A. A. (2014). Pengembangan Modul Biologi Berbasis Inkuiri Terbimbing Pada Materi Pokok Ekosistem Kelas X SMA Negeri 1 Tambusai. Jurnal Penelitian Pendidikan, 7.

H Dewi, R Agustini \& E Susantini. (2017). Development Of Learning Guided Inquiry Model To Improve The Critical Thinking Skills Of Junior High School Students. Prosidding 1st International Graduate Symposium on Science, Engineering, Education, Languange and Culture (SEELC) "Strengthening the Quality of Education in Global Wired World” Surabaya August 21, 2017

Hidayati, N. (2016). Pembelajaran Discovery Disertai Penulisan Jurnal Untuk Meningkatkan Kemampuan Kerja Ilmiah Siswa Kelas VIII SMPN I Probolinggo. Jurnal penelitian pendidikan IPA. JPPIPA., Vol. I No. 16.

Isnani, \& Nuraida, D. (2020). Validitas Modul Biologi Kelas Vii Berbasis Problem Solving Pada Materi Pencemaran Lingkungan. SNasPPM, 5(2), 251-256.

Jaya, I. M, Sadia dan Arnyana. (2014). Pengembangan Perangkat Pembelajaran Biologi Bermuatan Pendidikan Karakter Untuk Meningkatkan Keterampilan Proses Dan Hasil Belajar Siswa SMP. E- Journal Program Pasca Sarjana Universitas Pendidikan Ganesha Program Studi IPA.

Kurmanto dan Sujari. (2014). Penggunaan LKPD Terahadap Prestasi Belajar Matematika Kelas VII SMPN 2 Girisubu Gunungkidul Tahun Pelajaran 2013/2014. Jurnal Pendidikan Matematika.

Mafidatun N \& Muchis. (2014). Pengembanagan LKPD Beroreintasi Keterampilan Berpikir Kritis Pada Materi Ikatan Kimia Kelas X SMA. Jurnal of Chemical Education vol. 3 no. 2 tahun 2014.

Prastowo, A. (2011). Panduan Kreatif Membuat Bahan Ajar Inovatif. Yogyakarta. Diva Press.

Setiawan, Wisanti, \& Ulfi. (2014). Penelitian Pengembangan LKPD Berbasis Keterampilan Proses Sains.

Sudarmini, Kosim, dan Santoso H. (2015). Pembelajaran Fisika Berbasis Keterampilan Proses Dengan Menggunakan LKPD Untuk Meningkatkan Keterampilan Berpikir Kritis Ditinjau Dari Sikap Ilmiah. Jurnal penelitian pendidikan IPA.

Tarmizi. (2010). Ketuntasan Belajar Siswa Melalui Penerapan Pendekatan Keterampilan Proses Pada Konsep Sistem Gerak Tumbuhan Di SMA Negeri 3 Pidie. Jurnal Pendidikan Biologi. Vol.1 (2): 50-58.

Thiagarajan, S.D., \& Semmel, M. I. (2011). Instruksional Development for Training Teachers of Exceptional Children. Bloomington Indiana: Indiana University.

Trianto. (2007). Penerapan Pembelajaran Lembar Kerja Siswa (LKPD) Sebagai Penunjang Media Virtual PHET Pada Pembelajaran Hukum Archimedes Untuk Siswa SMP. E- Journal Unesa Volume 01 Nomor 02 Tahun 2013. 